"Structural attributes of firms, irreversibility, and uncertainty of corporate investment in Nigeria"

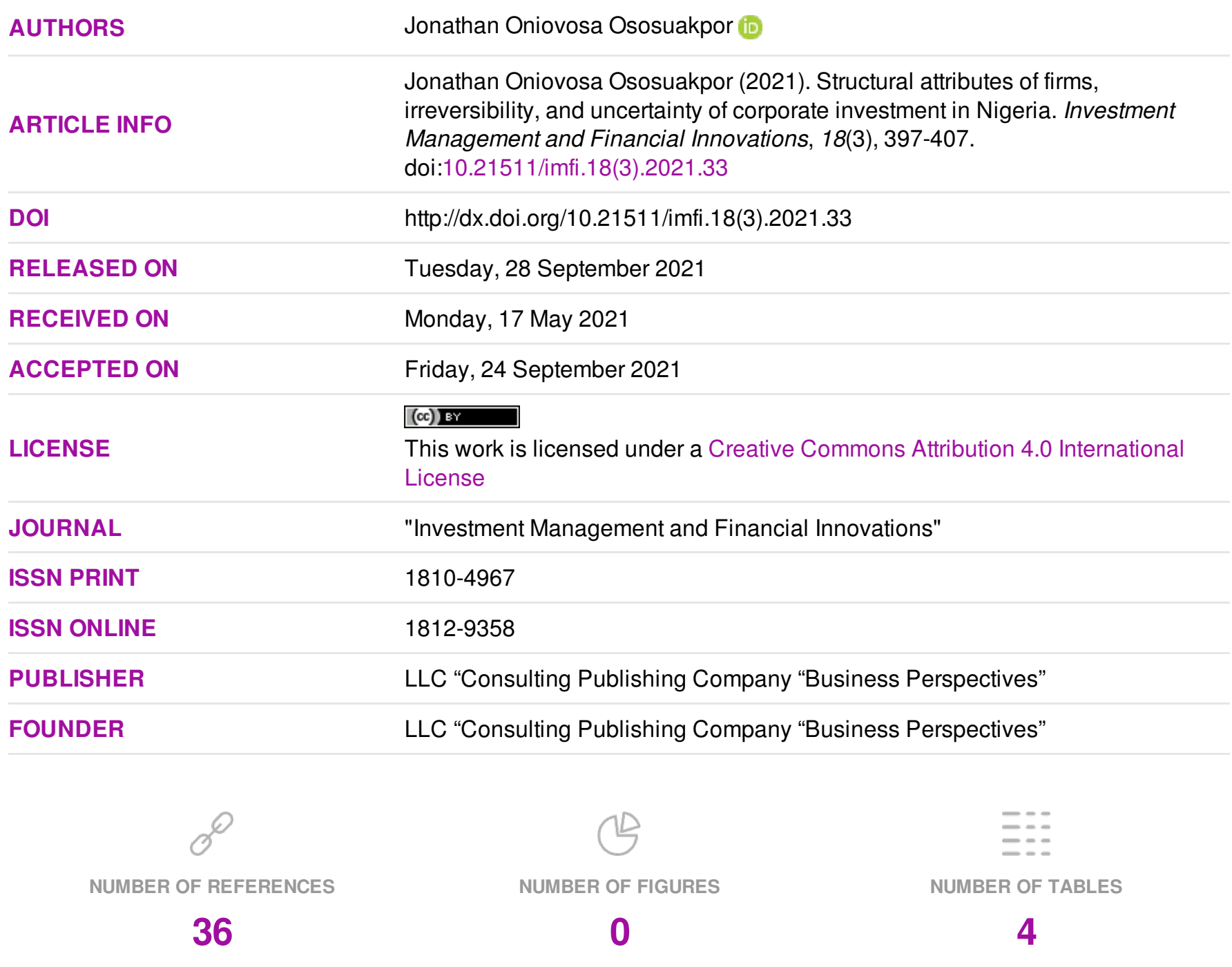

(C) The author(s) 2021. This publication is an open access article. 


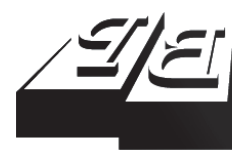

\section{BUSINESS PERSPECTIVES}

LLC "CPC "Business Perspectives" Hryhorii Skovoroda lane, 10, Sumy, 40022, Ukraine www.businessperspectives.org
Received on: $17^{\text {th }}$ of May, 2021 Accepted on: 24 $4^{\text {th }}$ of September, 2021 Published on: 28 ${ }^{\text {th }}$ of September, 2021

๑) Jonathan Oniovosa Ososuakpor, 2021

Jonathan Oniovosa Ososuakpor, Ph.D., Delta State University; AMJU Unique Microfinance Bank Limited, EffurunWarri, Delta State, Nigeria.
This is an Open Access article, distributed under the terms of the Creative Commons Attribution 4.0 International license, which permits unrestricted re-use, distribution, and reproduction in any medium, provided the original work is properly cited.

Conflict of interest statement: Author(s) reported no conflict of interest

Jonathan Oniovosa Ososuakpor (Nigeria)

\title{
STRUCTURAL ATTRIBUTES OF FIRMS, IRREVERSIBILITY, AND UNCERTAINTY OF CORPORATE INVESTMENT IN NIGERIA
}

\begin{abstract}
In the Nigerian context, there is a gap in the literature on the structural attributes of firms and the extent to which corporate investments are irreversible. Thus, this study was to empirically examine the structural attributes of firms, irreversibility, and un certainty of corporate investment using the real options theory of investment. The study is based on annual data series of firms listed on the Nigerian Stock Exchange from 2005 to 2019. The study measured structural attributes using competitiveness and monopoly/oligopoly of a firm, macroeconomic uncertainty, inflation, interest, and exchange rates, and examines their association with corporate investments. The study was conducted using a panel dataset adopting a fixed-effect estimation technique that takes into account potential endogeneity and firm specific-effects. The result showed that the macroeconomic uncertainty measure of exchange rate volatility is strongly detrimental to corporate investment decisions. Furthermore, interest rate and inflation volatilities are not detrimental to investment growth, while exchange rate uncertainty has a substantial negative influence on corporate investment. Besides, macroeconomic uncertainty was found to be a greater disincentive for firms with irreversible investments than for firms with more easily reversible investment projects.
\end{abstract}

Keywords

JEL Classification

\section{INTRODUCTION}

In the economics literature, investment has been widely acknowledged as one of the most volatile components of the national output of realizing sustainable economic growth. However, over the past decades, Nigeria's investment profile has looked very alarming. For instance, from 2001 to 2012, the average share of investment in the gross domestic product (GDP) is nine percent, and a decline has been witnessed in recent years (Okoro, 2014), which is quite unimpressive compared to the investment profile of other countries in sub-Saharan Africa (SSA).

Broadly speaking, diverse factors can affect corporate investment, one of which, according to Jung and Kwak (2018), and Khan et al. (2020), could be the extent of uncertainty about future events. Lately, researchers are keen in attempting to fathom the nature of the uncertainty-investment relationship, both at the market and firm levels. However, the nature of this relationship is yet inconclusive (see Khan et al., 2020; Machokoto et al., 2020; Jung \& Kwak, 2018; Tanaka, 2016). Uncertainty is a factor that is pertinent in an environment in which investors have difficulties in predicting future events (Ejedegba, 2006; Kalu \& James, 2012; Oriavwote \& Oyovwi, 2013). 
In developing countries, including Nigeria, they are highly volatile in nature, with prevailing information problems arising from deficient markets and institutions (Ninh et al., 2000; Ajide \& Lawanson, 2012). Inefficient capital markets result in wrong price signals that could affect the efficiency of resource allocation for effective investment, which could slow down the growth of an economy (Edo, 2005; Ifada et al., 2019).

Remarkably, investment paradigms have long ignored the relevant features of investment behavior, since investment expenditure may be irreversible, and investors may decide to delay in investing their money if they perceive that there is uncertainty about market indicators of prices for goods, costs of inputs and other dynamics necessary for economic agents to make investment decisions (Khan et al., 2019; Bernanke, 1983; Jorgenson, 1971). Dissimilar investment models have been developed to assess corporate investment, since it is perceived that when investment projects are correctly valued, it will assist investors in making valuable decisions that could help a firm to make workable financial commitments for the survival of the firm via the channel of profitability or value creation. However, the prevailing net present value and discounted cash flow techniques seem inept in capturing all the important factors that could influence investment decisions (Muzurura, 2018), hence the consideration of the real options theory of investment.

The real options theory advocates that uncertainty adversely influences investments in the area of irreversible capital by obtaining the utmost information, which stemmed from delay (Kang et al., 2014; Julio \& Yook, 2012; Bekoe \& Adom, 2013 cited in Muzurura, 2018). Admittedly, studies on irreversibility and uncertainty of corporate investment in Nigeria and other sub-Saharan Africa nations are available in the literature (see Machokoto et al., 2020; Oriavwote \& Oyovwi, 2013; Ajide \& Lawanson, 2012; and Kalu \& James, 2012), but most of these studies used traditional methods to determine factors relevant for a firm's decision to invest.

The traditional approach has not given room for flexibility as it relied largely on net present value criteria for investment selection and so it seems to be giving a conflicting picture of what determines investment (Pindyck, 1991). Again, to overcome the methodological bottleneck of relevant valuation models of investments, there is a need to develop valuation models capable of capturing features of investment such as irreversibility, uncertainty and, more importantly, how the structural attributes of firms (competition and monopoly/oligopoly) affect corporate investment in Nigeria.

\section{LITERATURE REVIEW}

The prerequisite to consider the structural attributes of the market in which firms are located cannot be over-emphasized, since it is very relevant when studying the relationship between corporate investment and uncertainty in the standard real options theory (ROT) of investment in the conditions of irreversibility and uncertainty (Khan et al., 2020). The ROT of irreversible investment decisions under uncertainty was proposed by Bernanke (1983) and Dixit and Pindyck (1994).

Predominantly, ROT is the only methodology that emphasizes the positive potential for uncertainty, and this is based on the argument that uncertainty can sometimes be a source of added value for investors who are able to take advantage of it. According to Dixit and Pindyck (1994) cited in Kang et al. (2014), at the core of the ROT approach are two elements, namely the ability of individuals or investors to learn from what is happening around them, and their willingness and ability to change behavior through learning. In other words, the ROT approach uses current and updated knowledge or information to empower opportunities while reducing uncertainty or danger.

Given the options framework, Koetse et al. (2009) noted that investors should take the following three important steps, namely: First, by relying on the fortune to increase the possible profit, and this is called the option to expand; second, the investor must reduce or abandon investments when 
the information received contains bad news, and this is called an option of abandonment, and this will allow a rational economic agent to cut losses; and third, it helps to deter further investment if the information suggests ambivalence about the prospects, and this is called a delay or wait option.

The purpose of the delay is to give investors time to gather further information with the expectation that market information will make the investment attractive (Kang et al., 2014). The ROT approach demonstrates that the opportunity cost is proportional to the level of investment uncertainty as well as the degree of irreversibility (Khan et al., 2020; Machokoto et al., 2020). As uncertainty increases, the value of a flexible strategic position increases relative to a more irreversible one (Tanaka, 2016). Considering the total uncertainty, rather than just the systematic component of it, is an important feature that distinguishes the ROT from traditional investment theory.

Most studies on structural attributes, irreversibility and uncertainty of corporate investments have long recognized that models based on simple rules of discounted factor are weakened by the fact that they do not take into account the opportunity cost of irreversibility when investments in capital are sunk cost (Abel, 1983; Arrow, 1968). The structural attributes of firms are about monopoly, oligopoly, and competitiveness, and it is assumed that small and large firms make investment decisions albeit competitive interactions.

Practically, competition can influence the relationship between investment and uncertainty. For instance, Caballero (1991) and McDonald and Siegel (1986) showed that imperfect competition negatively intensifies the relationship between investment uncertainty. A monopolistic firm can simply delay its investment as an investment opportunity is always available at any time when it decides to do so (Muzurura, 2018). This argument may also apply to an oligopolistic firm, probably to a lesser extent.

In case of divergence, if a firm operating in a competitive environment stays too long, its competitors will seize the investment opportunity. Thus, the firm invests quickly to stay ahead of the competition (Khan, et al., 2020; Abel \& Eberly, 1994).
In this case, the value of the wait option becomes less (Khan et al., 2020; Grenadier, 2002, Luehrman, 1998). Consequently, competition reduces the negative impact of uncertainty on firms investment.

In addition, when examining the relationship between investment and uncertainty, it is important to consider the size of firms (Jung \& Kwak, 2018). This is because small firms may lack managerial expertise, which limits their ability to mitigate the adverse effects of likely chang4e (Dibiasi, Abberger, Siegenthaler \& Sturm, 2018). This would mean that investment by small firms is subject to more undesirable effects of uncertainty.

Besides, if relinquishment costs are snowballing with the size of the firm, comparable investments may be viewed by larger firms as more irreversible than smaller ones (Jung \& Kwak, 2018). Uncertainty, through the channel of irreversibility, may have a more negative impact on investment by larger firms than smaller ones. According to these arguments, the effect of firm size on the investment-uncertainty ratio appears to be ambiguous (Oriani \& Sobrero, 2008 cited in Jung and Kwak, 2018); this, therefore, creates a gateway for further study on corporate investment, particularly for developing economies like Nigeria.

Corporate investments may be grouped by four broad categories such as public domestic, private domestic, foreign direct, and portfolio investments (Okoro, 2014). Public domestic investment includes government and public enterprise investment in social and economic infrastructures, real estate, and tangible assets, while private domestic investment refers to the formation of gross fixed capital plus net changes in the level of inventories. The combination of public investment and private investment is called gross fixed capital formation, and this distinguishes them from foreign investment.

Bakare (2011) notes that foreign investment is mainly related to tangible assets and is called direct foreign investment. It is called portfolio investment if it is linked to the markets for bonds, shares, and other securities such as derivatives. According to Jangilli and Kumar (2014), corporate investment is used interchangeably with private investment, so corporate investment is conceptu- 
alized as the amount of capital spent on increasing a firm's total assets.

Corporate investments could be financed either from internal sources of funds, such as accumulated earnings in the form of retained earnings, provision for asset decay (depreciation), or from external sources of financing, such as borrowing in the money market, fresh capital injection through the capital market among other things. According to Oriani and Sobrero (2008) cited in Jung and Kwak (2018), at the micro-level, private investment behavior is characterized by two main decisions such as investment financing and profit allocation. Noteworthy is the fact that firms have limited resources that must be optimized among competing uses, hence the very essence of firms watching critically to make appropriate investment decisions in order to obtain optimal profit and sustainability of their enterprise, despite the irreversibility of investments.

Since the late 1980s, several authors have emphasized the fact that irreversibility of investment is a vital factor that can have an impact on corporate investment decisions of firms (Bertola \& Caballero, 1994; Bernanke, 1983; McDonald \& Siegel, 1986). According to Khan et al. (2020) and Jung and Kwak (2018), the irreversibility of investment implies a situation where the machinery and equipment that the firm uses may be difficult to dispose of, or that the resale price may be significantly lower than the cost of replacement.

Similarly, irreversibility reduces the chances of firms disposing of, used physical capital to be able to survive in periods of downturn in an economic environment, and this may make the firm postpone or suppress investment at the time when uncertainty is prevalent in the economy; irreversibility raises the cost of capital and eventually increases the threshold value of investment.

Correspondingly, when the investment capital cost is irreversible, they introduce an option value to postpone investment when there is additional information about a future event (Kang, et al., 2014). Moreover, when the uncertainty level prevailing in the economy is high, the value of being able to restrain or reduce investment projects increases, leading to lower current investment costs.
Furthermore, investments outside the firm or industry are often partially irreversible because buyers in the second-hand goods markets may not be able to assess the quality of the goods and the offer price that matches the average quality in the market (McDonald \& Siegel, 1986). On the other hand, sellers who know the quality of the goods they are selling may be reluctant to sell above-average price in the market, in which case they try to establish a meeting point between the buyer's and seller's price. This eventually leads to selling stock of investment below-cost or its book value. This is what is termed as the "lemons problem" that plagues many of these markets (Akerlof, 1970).

Irreversibility can arise due to government regulations or institutional arrangements. For instance, government controls on capital could prevent investors from selling assets and reallocating their resources. Similarly, investment in new workers may be partly irreversible due to high costs of hiring and training workers (Pindyck, 1991), so most capital expenditures are in part, irreversible (Khan et al., 2020; Jung \& Kwak, 2018; Tanaka, 2016).

Again, studies on the nature of the relationship between investment and uncertainty have been concerned with the decisions of firms that are competitive with irreversible investments in the developed world and other regions outside Nigeria. While empirical models have shown mixed results, most studies seem to show the undesirable effects of uncertainty on firm investment due to irreversibility.

For instance, Khan et al. (2020) examined the link between diverse uncertainties and corporate investment in public and private enterprises in China over the period 1999-2016. To control for endogeneity, a two-step Generalized Method of Moments (GMM) was used, and the results showed that market and firm-specific uncertainties positively affect corporate investment. Contrarily, the study found that economic policy-based uncertainties negatively affect corporate investment. In addition, it was found that cash flow stimulates the effect of firm-specific uncertainty on state-owned enterprises' investment and weakens non-stateowned enterprises. 
Jung and Kwak (2018) studied the R\&D investment behavior under uncertainty in Korea that depends on a firm's characteristics. The GMM results showed that firm size and innovation capacity positively moderate the negative link between uncertainty and R\&D investment.

In Japan, Tanaka (2016) evaluated the association between the impact of uncertainty on fixed investment and industrial attributes based on a set of manufacturing firms' panel data. The study assesses the extent of competition in the product markets and the irreversibility of capital goods using an autoregressive model. The results showed that less competition in the product market is associated with a greater negative effect of uncertainty on investment. Moreover, the study showed that the effect of uncertainty on investment is negative and significant for industries with more irreversible capital goods with a low likelihood of disposal in the second-hand market.

In Nigeria, Oriavwote and Oyovwi (2013) investigated the behavior of corporate investment using 1980-2011 data. The result indicates that government spending on building and developing infrastructures has been beneficial to corporate investors. Besides, Johansen co-integration test supports the long-run relationship between variables, and a significant and negatively signed error correction model suggests a satisfactory speed of adjustment.

Ajide and Lawanson (2012) assessed the determinants of domestic private investment in Nigeria during the period 1970-2010. Variables of public investment, gross domestic product, the real rate of interest, rate of exchange, credit to the private sector, terms of trade, external debts, and reform dummies were used. The study found that public investment, real gross domestic product, and terms of trade are statistically significant in the short run.

Bakare (2011) examined the determinants of private domestic investment in Nigeria using time-series data and an error correction mechanism. The results suggest that political upheavals may have created a climate hostile to private investment, but the overall measure of political and macroeconomic instability is an obstacle to private investment in Nigeria.
While it is recognized that there are robust studies on corporate investment in Nigeria around the world, as far as is known, there are no valuation models capable of capturing features of investment such as irreversibility, uncertainty, and how structural attributes of firms (competition and monopoly/oligopoly) affect corporate investments in Nigeria. Given the gap in the literature, this study hypothesizes that structural characteristic of firms and the extent to which corporate investment is irreversible have no significant influence on the relationship between corporate investment and uncertainty.

\section{METHOD}

In this paper, the ex-post facto research design was employed. According to Kerlinger (1986) cited in Okoro and Ekwueme (2020), this design is adequate as it is a substitute for true experimental research. More so, this design is justifiable, since the dataset used is obtained from secondary sources. The study population consists of data obtained from one hundred and sixty-one (161) firms publicly quoted on the Nigerian Stock Exchange as of December 31, 2019.

For relevance and consistency, data on financial institutions were screened out, retaining those on the real sectors of the economy. This is because the study was about the real sector of the economy, not portfolio investment, and therefore it was necessary to screen out finance companies. Again considering data availability and continuity, the total population was further screened and ended up with a clean sample of 73 firms. For these samples, Nigeria investment determinant variables based on the real options theory of investment were constructed.

The data used were classified as irreversible investment capital, firms that are competitive and monopolistic in their market structure. The data series for the models spanned from 2005 to 2019 and were obtained from the Nigerian Stock Exchange, Bureau of Statistics, and the Central Bank of Nigeria's statistical bulletin. The most appealing model to empirically determine the investment-uncertainty relationship offered by 
Sakar (2000) on real option pricing theory was adapted. To test for the threshold effects of the investment-uncertainty relationship, following Sakar (2000) on the real options model, the following models were specified:

$$
\begin{aligned}
& I / K=\alpha_{0}+\alpha_{1} U m L+\alpha_{2} U m H+\varepsilon, \\
& I / K=\alpha_{0}+\alpha_{1} U m L+ \\
& +\alpha_{2} U m H+\alpha_{3}(I / K)_{t-1}+\psi V \varepsilon,
\end{aligned}
$$

where $I / K$ - ratio of corporate investment to capital stock; $U m L$ - proxy for linear uncertainty measure - low measure of uncertainty; $U m H$ proxy higher uncertainty measure - high measure of uncertainty; and $(I / K)_{t-1}$ - lagged investment to capital ratio.

To test the robustness of the results, equation 2 was set to estimate a dynamic investment model with a lagged investment-to-capital ratio. Bo et al. (2001) opined that most empirical investment studies do account for the lag dependent variable, since investment decision is a dynamic issue. The lag dependent variable is taken into account to allow for a conceivable dynamic structure in the model that could be caused by the inertia of the dependent variable.

In addition, a conceivable advantage of adding lagged term is that it may eliminate serial correlation. The dependent variable is the ratio of gross corporate investment to capital stock. Uncertainty constitutes the main variable of interest in this study, and indeed, the inclusion of uncertainty terms in the model is motivated by theoretical and empirical literature, suggesting that uncertainty may affect firms' investment decisions. Since firms in Nigeria face various types of uncertainty and do not know which of the uncertainty impact most on investment decisions of firms, another model of investment is specified that incorporates different proxies of macroeconomic uncertainty faced by individual firms into equation (3), thus:

$$
\begin{aligned}
& I / K=\alpha_{0}+\alpha_{1} u_{m L}+\alpha_{2} U_{m H}+ \\
& +\alpha_{3}(1 / k) t_{-1}+\beta_{1} \text { Ureer }+ \\
& +\beta_{2} \text { Urint }+\beta_{3} \text { Uinf }+\varepsilon,
\end{aligned}
$$

where Ureer - volatility of exchange rate; Urint volatility of interest rate; and Uinf - inflation rate volatility. All other variables specified in equation 3 are as previously defined.

To test the threshold effects of the investment-uncertainty relationship as implied by the real options model of Sarkar (2000), a simple Q-type model of investment is specified, extended by the linear and a quadratic term for uncertainty, using Nigerian firms' dataset. The prediction equation was estimated using fixed effects and Generalized Least Squares (GLS). The fixed-effect model accounts for the potential existence of heteroskedasticity and was adopted to account for individual-specific effects. This means that each firm has its intercept reflecting individual heterogeneity.

There is also the assumption of the possible existence of individual firm's homogeneity, and upon this assumption, an alternative equation was estimated using the common intercept model also referred to as the pooled model. This means there is no unobservable characteristic that makes the firm heterogeneous. The choice of fixed effect is on the premise that members of the pool (individual firms) were selected on a random basis rather on data consideration, which is the case in most panel studies where the individuals are firms or countries. Thus it is appropriate to adopt the fixed effect model. Besides, the fixed effect accounts for unobservable individual-specific effects; however, fixed effect and GLS estimation methods have their drawbacks.

In this study, volatility of variables was measured using standard deviation and, where applicable, Generalized Autoregressive Conditional Heteroskedasticity (GARCH) models. For market uncertainty, a panel data estimation technique was used, while for uncertainty proxies, the study used GARCH (1 1 ) for data with high volatility, and for low volatility, standard deviation from a geometric Brownian process was used. The preference for these uncertainty measures over the other measures can be justified by the fact that financial markets could react nervously to macroeconomic crises. 
Following Lensink et al. (2001) and in line with the existing literature, there are five main methods of constructing an uncertainty proxy: standard deviation, standard deviation of volatile portion of a stochastic process, standard deviation of a geometric Brownian process, the GARCH model of volatility, and standard deviation derived from survey data. This study explored the five measures as much as possible, given the point that the GARCH model has a different stationarity process compared to the real options model. Specifically, the study adopted the GARCH model of volatility, which assumes that the variance of the error terms is not constant over time, and this is often the case with the stock market data.

Irreversibility may lead to postponement or suppression of investment during the period of uncertainty, since it decreases the likelihood of firms selling used physical capital to survive the downturn of the economic environment. Irreversibility, therefore, is important and should be accounted for when examining corporate investment determinants in the real options theory paradigm. Since firms are classified into competitive and monopoly firms based on the stock exchange local industry classifications, an interactive dummy variable for the use in the regression is constructed to show how market structure influences investors' uncertainty decisions. Thus, competitive firm (Com) was set equal to 1 (i.e. Com =1), and zero otherwise $(\mathrm{Com}=0)$.

\section{RESULTS}

Table 1. Descriptive statistics of variables

\begin{tabular}{l|c|c|c} 
& \multicolumn{3}{c}{ Source: Computed by the author using STATA. } \\
\hline Statistics & IK & UM & UM2 \\
\hline Mean & 3.36280 & 11.96387 & 561.0436 \\
\hline Median & 2.12912 & 3.87905 & 11.56406 \\
\hdashline Maximum & 231.4614 & 124.07590 & 14812.69 \\
\hline Minimum & 0.00675 & 0.01458 & 0.00020 \\
\hline Std. Dev. & 11.88683 & 21.43803 & 1906.840 \\
\hdashline Skewness & 14.31250 & 3.12248 & 4.62585 \\
\hdashline Kurtosis & 229.9550 & 12.36219 & 24.51965 \\
\hdashline Sum & 2945.826 & 10480.34 & 491474.1 \\
\hline Sum Sq. Dev. & 118959.5 & 386933.6 & $3.06 \mathrm{E}+09$ \\
\hline
\end{tabular}

Table 2. Descriptive statistics of market uncertainty of the investment model

Source: Computed by the author using STATA

\begin{tabular}{c|c|c|c|c}
\hline Period & Mean IK & Sd IK & Mean UM & Sd UM \\
\hline 2005 & 5.259251 & 25.82027 & 13.97030 & 22.12847 \\
\hline 2006 & 3.028980 & 6.817581 & 13.93160 & 21.85487 \\
\hline 2007 & 4.220916 & 16.27590 & 13.69343 & 21.38910 \\
\hline 2008 & 4.400878 & 18.16911 & 13.75389 & 21.81086 \\
\hline 2009 & 3.314066 & 7.142833 & 14.00341 & 22.71009 \\
\hline 2010 & 3.151125 & 6.916520 & 14.21723 & 23.85491 \\
\hline 2011 & 3.575278 & 7.732257 & 14.53816 & 25.32901 \\
\hline 2012 & 3.070425 & 6.925498 & 12.61553 & 23.42123 \\
\hline 2013 & 2.965579 & 6.825969 & 7.614814 & 14.06418 \\
\hline 2014 & 2.058642 & 3.308574 & 5.633629 & 11.46609 \\
\hline 2015 & 1.951293 & 1.918234 & 5.192320 & 12.19916 \\
\hline 2016 & 1.831411 & 1.363371 & 8.973274 & 19.33039 \\
\hline 2017 & 1.711529 & 0.808508 & 12.75423 & 26.46162 \\
\hline 2018 & 1.591647 & 0.253645 & 16.53518 & 33.59285 \\
\hline 2019 & 1.471765 & 1.41094 & 20.31614 & 40.72408 \\
\hline & & & & \\
\hline
\end{tabular}

The annual averages shown in Table 1 indicate that investment scaled by the size of capital stock was generally on the fall over the study period, as reflected by the increasing standard deviation. From the table, investment witnessed a steady dip over the period 2005-2019, implying that unguided liberalization of the economy could be detrimental to investment, particularly if domestically produced goods are not internationally competitive.

Table 3. Effect of irreversibility on corporate investment in Nigeria

Source: Computed by the author using STATA

Dependent Variable: LNIK

\begin{tabular}{|c|c|c|c|c|}
\hline \multicolumn{5}{|c|}{ Linear estimation after one-step weighting matrix } \\
\hline Variable & Coefficient & $\begin{array}{l}\text { Std. } \\
\text { Error }\end{array}$ & $t$-Statistic & Prob. \\
\hline C & -0.34954 & 0.33057 & -1.09895 & 0.30212 \\
\hline LNUM & -0.00048 & 0.01595 & -0.03137 & 1.01425 \\
\hline$L N I K(-1)$ & 0.25699 & 0.03918 & 6.81679 & $0.0000 * * *$ \\
\hline IREV & 0.00283 & 0.00135 & 2.18066 & $0.03762 * *$ \\
\hline$R$-squared & 0.92904 & \multicolumn{2}{|c|}{ Mean dependent var } & 1.18718 \\
\hline $\begin{array}{l}\text { Adjusted } \\
R \text {-squared }\end{array}$ & 0.91648 & \multicolumn{2}{|c|}{ S.D. dependent var } & 1.28377 \\
\hline $\begin{array}{l}\text { S.E. of } \\
\text { regression }\end{array}$ & 0.44320 & \multicolumn{2}{|c|}{ Sum squared resid } & 136.076 \\
\hline F-statistic & 76.88949 & \multicolumn{2}{|c|}{ Durbin-Watson stat } & 2.09292 \\
\hline
\end{tabular}

Note: The standard errors are heteroskedasticity consistent. $*, * *$, and $* * *$ denote statistical significance at $10 \%, 5 \%$, and $1 \%$, respectively. IREV = Irreversibility of investment (factor shaping the uncertainty impact on corporate investment). All other variables in this model are as previously defined. 
Table 3 considers the effect of irreversibility on the investment-uncertainty relationship. As for the the interaction of the irreversibility indicator with the uncertainty terms, it is observed that irreversibility of investment capital is a relevant factor influencing a firm's decision in Nigeria. The coefficient of the interaction term (irreversibility) is considerably small but statistically significant at a 5 percent level. A striking observation is that upon the interactive term, the estimated coefficients of the linear market uncertainty indicator showed substantial changes.

Specifically, the coefficient of linear market uncertainty changed from a positive value to a negative value, and other variables of the model displayed substantial changes in their form. Indeed, the coefficient magnitude and signs, as well as the level of statistical significance of the estimated standard investment determinants displayed reasonable changes. The coefficient of the uncertainty term is the slope coefficient for firms with more reversible investment $(I R E V=0)$, and the product of the interaction term is the slope coefficient for firms with more irreversible investment $(I R E V=1)$.

As Table 3 shows, the interaction term is statistically significant with the marginal improvement in the coefficient of the linear market uncertainty indicator $(U m)$, indicating that uncertainty decreases investment in the presence of irreversibility, as envisaged by the real options theory of investment. For further evidence bothering on the objectives of this study, the notion of a firm's deci- sion on corporate investment is applied, based on the structure of the market in which it operates. In this regard, the competitive and monopolistic/ oligopolistic structure of the market in which individual firms operate was considered.

Specifically, sensitivity of the results to the nature of the proposed sample firms (i.e. effect of competition/monopolistic nature of firms on investment-uncertainty relationship) was explored (see Table 4). With regard to the interaction of the market structure indicator with the uncertainty variable, the coefficient of the market uncertainty term was visibly upturned from the positive posture it took previously and became negative with the value of -0.00748 , although with relatively low magnitude.

The coefficient of uncertainty term is the slope of the coefficient for firms that are monopolistic (i.e. com $=0$ ), and the product of interaction term is the slope of coefficient for competitive firms (i.e. com =1). The outcome of the interactive term is positive and statistically significant, but the coefficient of the linear market uncertainty indicator remains negative, quite negligible, and statistically insignificant, suggestive that uncertainty affects investment decisions, but not necessarily influenced by the market structure in which the firm operates in Nigeria.

Regarding the diagnostic statistics, the R-Squared of various models generally suggests that the explanatory variables are capable of explaining

Table 4. Structural attributes of firms and corporate investment (Com)

Source: Computed by the author using STATA.

\begin{tabular}{|c|c|c|c|c|}
\hline \multicolumn{5}{|c|}{ Dependent Variable: LNIK } \\
\hline \multicolumn{5}{|c|}{ Linear estimation after one-step weighting matrix } \\
\hline Variable & Coefficient & Std. Error & t-Statistic & Prob. \\
\hline C & -0.33720 & 0.32944 & -1.06378 & 0.31844 \\
\hline LNUM & -0.00748 & 0.01651 & -0.47071 & 0.67627 \\
\hline$L N I K(-1)$ & 0.25332 & 0.03921 & 6.71411 & $0.0000^{* * *}$ \\
\hline COM & 0.00505 & 0.00206 & 2.55145 & $0.01486 * * *$ \\
\hline$R$-squared & 0.93299 & \multicolumn{2}{|c|}{ Mean dependent var } & 1.18162 \\
\hline Adjusted $R$-squared & 0.92088 & \multicolumn{2}{|c|}{ S.D. dependent var } & 1.29535 \\
\hline S.E. of regression & 0.44133 & \multicolumn{2}{|c|}{ Sum squared resid } & 134.934 \\
\hline F-statistic & 80.0879 & \multicolumn{2}{|c|}{ Durbin-Watson stat } & 2.09082 \\
\hline
\end{tabular}

Note: The standard errors are heteroskedasticity consistent. *,**, and $* * *$ denote statistical significance at $10 \%, 5 \%$, and $1 \%$, respectively. IREV = Irreversibility of investment (factor shaping the impact of uncertainty on corporate investment). All other variables in this model are as previously defined. COM = market structure in which firms operate (a factor shaping the uncertainty impact on corporate investment). 
changes in the dependent variable. Similarly, the outcome of the Durbin-Watson statistics suggests the absence of higher-order auto-correlation. Table 4 shows that the irreversibility of investment capital is a relevant factor influencing a firm's investment decisions in Nigeria. The coefficient of the interaction term is considerably small at 0.00283 (see Table 3), but statistically significant at a $5 \%$ significance level.

The result (Table 4) shows that the coefficient of the interactive factor, i.e. market structure, is 0.00505 and is statistically significant at the $1 \%$ level, but the coefficient of the linear market uncertainty indicator remains negative at -0.00748 , which is quite negligible and statistically insignificant; this indicates that uncertainty affects corporate investment decisions, but is not necessarily influenced by the market structure on which firms operates in Nigeria. Consequently, the hypothesis that the structural attributes of the market have no significant impact on corporate investment in Nigeria is accepted.

\section{DISCUSSION}

Social science researchers, especially economists, have long been interested in additional research on what determines investment, especially in an environment where it is difficult to obtain information firms need to determine prospects. Diverse theoretical models on investment determinants have made opposing predictions about what factors determine investment in developing countries, of which Nigeria is a part, indicating the need for empirical verification. Most of the empirical studies on the issue were based on an aggregate data set, in addition to failing to control for potential relevant investment determinants, leading to misleading predictions in many cases.

Based on the relationship between corporate investment and market uncertainty, the results of this study are quite ambiguous for Nigeria firms. The regression result was imprecise and, therefore, could not establish a discernible relationship, as posited in real options theory of investment. Under certain circumstances, the relationship is positive, while under other circumstances, the relationship turns otherwise.

Furthermore, it was found that irreversibility increases the negative association of corporate investment with the market uncertainty variable, but this result is reversed when the sampled firms are competitive. The results are consistent with Khan et al. (2020), Jung and Kwak (2018), and Tanaka (2016) that the effect of uncertainty may be stronger for less competitive firms.

\section{CONCLUSION}

This study assessed the structural attributes of firms, irreversibility, and uncertainty of corporate investment, using a panel of Nigerian firms listed on the Stock Exchange from 2005 to 2019, to ascertain the factors that are most relevant to forward-looking investors. The result obtained revealed that under certain circumstances, the relationship between structural attributes of firms and uncertainty of corporate investment is positive, while it turns otherwise under other circumstances. It was also found that irreversibility increases the negative association of corporate investment with the market uncertainty variable, but this result is reversed when the sampled firms are competitive. Again, the regression result was imprecise and, therefore, unable to establish a discernible relationship, as posited in the real options theory of investments.

Given the findings, the study recommends the prompt development of non-depository financial institutions that would act as financial intermediaries and ensure competition with depository banks to verify their behavior and, as a result, improve the efficiency of investments in the financial system. In addition, the study advocates diligent and disciplined implementation of stable macroeconomic policy measures for sustainable economic development through increased investment. 


\section{AUTHOR CONTRIBUTIONS}

Conceptualization: Jonathan Oniovosa Ososuakpor.

Formal analysis: Jonathan Oniovosa Ososuakpor.

Funding acquisition: Jonathan Oniovosa Ososuakpor.

Investigation: Jonathan Oniovosa Ososuakpor.

Methodology: Jonathan Oniovosa Ososuakpor.

Writing - original draft: Jonathan Oniovosa Ososuakpor.

Writing - review \& editing: Jonathan Oniovosa Ososuakpor.

\section{REFERENCES}

1. Abel, A. B. (1983). Optimal investment under uncertainty. American Economic Review, 73, 228-233. Retrieved from https:// ideas.repec.org/a/aea/aecrev/ v73y1983i1p228-33.html

2. Abel, A. B., \& Eberly. (1994). A unified model of investment under uncertainty. American Economic Review, 5(84), 1369-1384.

3. Ajide, D., \& Lawanson, R. (2012). Modeling the long-run determinants of domestic Private investment in Nigeria. Asian Social Science, 8(13). https://doi. org/10.5539/ass.v8n13p139

4. Akelof, G. (1970). The market for lemon: Quality uncertainty and the market mechanism. Quarterly Journal of Economics, 84(3), 488500.

5. Arrow, K. (1968). An optimal policy with irreversible investment. In J. N. Wolfe (Ed.), Value, capital, and growth (pp. 1-19). (Paper in honor of Sir John Hicks). Chicago Aldine Publishing Company.

6. Bakare, A. S. (2011). The determinants of private domestic investment in Nigeria. Far East Journal of Psychology and Business, 4(2). Retrieved from https:// ideas.repec.org/a/fej/articl/v4by2011i3p27-37.html

7. Bernake, B. S. (1983) Irreversibility, uncertainty and cyclical investment. Quarterly Journal of Economics, 98, 85-106. https://doi.org/10.2307/1885568

8. Bertola, G. N. S., \& Caballero, R. (1994). Irreversibility and aggregate investment. Review of
Economic Studies, 61, 223-246. https://doi.org/10.2307/2297979

9. Bo, H., Lensink, R., \& Sterken, E. (2001). Uncertainty and financing constraints. European Finance Review, 7, 297-321. https://doi. org/10.1023/A:1024570312059

10. Caballero, R. (1991). On the sign of the investment - uncertainty relationship. American Economic Review, 81, 279-288. Retrieved from https://www.proquest.com/ docview/233046623

11. Dibiasi, A., Abberger, K., Siegenthaler, M., \& Sturm, J. E. (2018). The effects of policy uncertainty on investment: Evidence from the unexpected acceptance of a far-reaching referendum in Switzerland. European Economic Review, 104, 38-67. Retrieved from https://econpapers.repec.org/ article/eeeeecrev/v_3a104_3ay_3a 2018_3ai_3ac_3ap_3a38-67.htm

12. Dixit, A. K., \& Pindyck, R. S. (1994). Investment under uncertainty. Princeton, NJ: Princeton University Press. https:// doi.org/10.2307/j.ctt7sncv

13. Edo, S. E. (2005). Recent evidence on stock market inefficiency in a developing economy. International Journal of Economic Research, 2(1), 1-16.

14. Ejedegba, R. U. (2006). The relationship between corporate investment and uncertainty. Evidence from SSA firms. (Unpublished Ph.D. thesis). Benin-city: University of Benin.

15. Grenadier, S. R. (2002). Option exercise games: An application to the equilibrium investment strategies of firms. The Review of Financial Studies, 15, 691-721. Retrieved from https://www. semanticscholar.org/paper/ Option-Exercise-Games\%3AAn-Application-to-the-of-Grenadier/b64df95ee4cb9dfe59930b74c72a139008125e5a

16. Ifada, L. M., Faisal, F., Ghozali, I., \& Udin, U. (2019). Company attributes and firm value: Evidence from companies listed on Jakarta Islamic index. Revista, 40(37), 1-14. Retrieved from https://www.revistaespacios.com/ a19v40n37/19403711.html

17. Jangilli, R., \& Kumar, S. (2014). Determinants of corporate sector investment in India. Reserve Bank of India Issue of 2014.

18. Jorgenson, D. W. (1971). Econometric studies of investment behavior. A Survey of Economic Literature, 9, 1-47. Retrieved from https://scholar.harvard.edu/jorgenson/publications/econometricstudies-investment-behaviorreview

19. Julio, B., \& Yook, Y. (2012).

Political uncertainty and corporate investment cycles. The Journal of Finance, 67(1), 45-83. https://doi.org/10.1111/j.15406261.2011.01707.x

20. Jung, S., \& Kwak, G. (2018). Firm characteristics, uncertainty, and research and development (R\&D) investment: The role of size and innovation capacity. Sustainability, 10(1688), 1-14. http://dx.doi. org/10.3390/su10051668

21. Kalu, I. E., \& James, O. E. (2012). Private investment in Nigeria and manufacturing sector: A VECM 
approach. Journal of Economics and Sustainable Development, $3(11)$.

22. Kang, W., Lee, K., \& Ratti, R. A. (2014). Economic policy uncertainty and firmlevel investment. Journal of Macroeconomics, 39, 42-53. Retrieved from https://ideas.repec. org/p/pra/mprapa/51277.html

23. Kerlinger, F. N. (1986). Foundation of behavioral research ( $3^{\text {rd }}$ ed.). Fort worth, TX: Holt Rinehart and Wilston.

24. Khan, M. A., Qin, X. Jebran, K., \& Rashid, A. (2020). The sensitivity of firms' investment to uncertainty and cash flow: Evidence from listed state-owned enterprises and non-state-owned enterprises in China. Sage Journal, March, 1-17. https://doi.org/10.1177\%2F2158244020903433

25. Koetse, M. J., Groot, H. L. F. D., \& Florax, R. J. G. M. (2009). A meta-analysis of the investmentuncertainty relationship. Southern Economics Journal, 76, 283-306. Retrieved from https://ideas. repec.org/a/wly/soecon/v76y2009ilp283-306.html

26. Luehrman, T. A. (1998). Investment Opportunities as real options: getting started on the number. Harvard Business Review, 76, 51-67. Retrieved from https:// hbr.org/1998/07/investmentopportunities-as-real-optionsgetting-started-on-the-numbers

27. Machokoto, M., Areneke, G., \& Ibrahim, B. M. (2020). Rising corporate debt and value relevance of supply-side factors in South Africa. Journal of Business Research, 109, 26-37. https://doi. org/10.1016/j.jbusres.2019.11.039

28. McDonald, R., \& Siegel, D. (1986). The value of waiting to invest. Quarterly Journal of Economics, 101, 707-727. https:// doi.org/10.2307/1884175

29. Muzurura, J. (2018). Firm-level investment decisions under uncertainty and irreversibility in Zimbabwe's private firms. International Journal of Business, Economics and Management, 5(6), 201-218. Retrieved from https://ideas.repec.org/a/pkp/ ijobem/2018p201-218.html

30. Ninh, L. K., Hermes, N., \& Lanjouw, G. (2000). Irreversible investment and uncertainty: An Empirical Study of Rice Mills in the Mekong River Delta, Vietnam.

31. Okoro, E. G. (2014). Oil price volatility and economic growth in Nigeria: A vector autoregression (VAR) approach. Acta Universitatis Danubius, 10(1), 70-82.
32. Okoro, E. G., \& Ekwueme, C. M. (2021). Is accounting alchemy still the right medicine for firm's earnings and book value? Evidence from Sub-Saharan Africa. Revista de Administração Mackenzie, 22(3), 1-27. https:// doi.org/10.1590/1678-6971/ eRAMF210007

33. Oriavwote, V. E., \& Oyovwi, D. O. (2013). Modeling private investment behavior in Nigeria: A co-integrated approach. Accounting, and Finance Research, 2(3). http://dx.doi.org/10.5430/afr. v2n3p14

34. Pindyck, R. (1991). Irreversibility, uncertainty, and investment. Journal of Economic Literature, 29(3), 1110-1148. https://doi. org/10.3386/w3307

35. Sarkar, S. (2000). On the investment-uncertainty relationship in a real options model. Journal of Economic Dynamic and Control, 24, 219-225. Retrieved from https://econpapers. repec.org/article/eeedyncon/v 3a24_3ay_3a2000_3ai_3a2_3ap_ 3a219-225.htm

36. Tanaka, K. (2016). Industrial characteristics and the investmentuncertainty relationship: A panel study of data on Japanese firms. International Journal of Finance and Accounting, 5(5A), 36-48. 